\title{
Kulturalno-oświatowa działalność w obozach internowanych w Polsce w kontekście ukraińskiej studenckiej emigracji
}

\section{Cultural and Educational Work in the Interned Camps in the Context of Ukrainian Student's Emigration}

Abstract: The article is devoted to the problem of cultural and educational work interned soldiers Army of Ukrainian National Republic in Polish camps at the beginning of 1920-es. Former soldiers were the main source for the Ukrainian interwar student's emigration in Poland. Circumstances of origin Ukrainian student's movement on the basis of military forces are underlined in the article.

Keywords: Army of Ukrainian National Republic, emigration, student's emigration, Poland Słowa kluczowe: Armia Ukraińskiej Republiki Ludowej, emigracja, emigracja studencka, Polska

W latach dwudziestych XX wieku Polska była znaczącym ośrodkiem emigracji ukraińskiej. Dużą część, spośród wszystkich emigrantów, stanowili studenci. Główną przyczyną ukraińskiej emigracji na początku XX wieku była klęska dążeń narodowo-wyzwoleńczych w latach 1917-1920, jednak na status polityczny emigrantów wpłynęły nie tylko konieczność opuszczenia ojczyzny, a bardziej charakter i cele ich działalności.

Podpisując tymczasowe porozumienie w Rydze 12 października 1920 r. przedstawiciele Polski i Rosji bolszewickiej wzięli na siebie zobowiązanie o zaprzestaniu działań wojennych. Faktycznie znaczyło to anulowanie umowy między Rzeczpospolitą a Ukraińską Republiką Ludową (URL), zostawiając ostatnią samą w walce z Rosją. Strategicznie niewygodna sytuacja wojsk ukraińskich, brak amunicji i sprzętu wojskowego bardzo komplikowały możliwość oporu Armii URL wobec wojsk bolszewickich. Zwłaszcza, że pod naciskiem władz dowództwo Wojska Polskiego zarządziło wycofanie z terytorium Polski wszystkich niepolskich formacji 
wojskowych. W razie ich powrotu miały zostać rozbrojone i internowane do specjalnych obozów'

Jeszcze na początku listopada 1920 r. Armia URL prowadziła walkę na terytorium Ukrainy, wstrzymując nacisk oddziałów wojsk bolszewickich. Jednak 21 listopada 1920 r. Armia URL musiała wejść na terytorium Polski, a wówczas jej oddziały zostały rozbrojone i internowane do kilku obozów w Polsce (Aleksandrów Kujawski, Wadowice, Piotrków, Pikulice, Łańcut i Kalisz). W grudniu 1921 r. wszystkie internowane ukraińskie wojska zostały rozmieszczone w trzech obozach: Kalisz, Szczypiorno i Strzałkowo. Trzy lata później, latem 1924 r. wszystkie obozy uwięzionych i internowanych Ukraińców w Polsce były likwidowane, a ich mieszkańcy otrzymali status emigrantów politycznych ${ }^{2}$.

Na początku lat dwudziestych XX w. w Polsce na ukraińską emigrację składali się głównie internowani wojskowi Armii Ukraińskiej Republiki Ludowej. Pod koniec lat dwudziestych większość emigrantów politycznych stanowili studenci. Ta zmiana spowodowana była likwidacją obozów dla internowanych, w wyniku czego większość ich mieszkańców szukając dla siebie cywilnego zajęcia podjęła edukację na wyższych uczelniach ${ }^{3}$. Jedną z przyczyn tego procesu było tworzenie w obozach dla internowanych różnych organizacji kulturowo-oświatowych, kółek amatorskich itp., które inspirowały do dalszej nauki (np. przygotowywały do podjęcia studiów wyższych $)^{4}$. Podobne kursy i koła organizowano we wszystkich krajach gdzie przebywali ukraińscy internowani wojskowi.

Istotną cechą ukraińskiego ruchu studenckiego na emigracji w okresie międzywojennym był wysoki poziom świadomości narodowej studentów i ich pragnienie utrzymania tożsamości opartej na historii i bogatej kulturze. Wśród głównych zadań, które sobie wyznaczali było: ochrona poczucia przynależności narodowej, dbanie o odrodzenie państwowości, informowanie innych państw o sytuacji politycznej Ukrainy, a przede wszystkim edukacja.

Początek ruchu ukraińskich studentów-emigrantów w Polsce datuje się od jesieni 1920 r. ${ }^{5}$ Zimą 1920/1921 r. w obozach dla internowanych wojsk ukraińskich

1 3. Карпус, І. Срібняк, Полонені та інтерновані вояки украйнці в таборах Польщі (1919-1920), Київ - Торунь 2001, s. 20.

2 Ibidem, s. 21.

3 О. Ауднік, Студентство як основна складова украӥнської політичної еміграчї̈ в 20-ті $p p$. $X X$ cm., [w:] Наукові записки Вінницького державного пеАагогічного університету ім. М. Коцюбинського. Серія: історія. - Випуск 4, 2002, s. 103.

4 І. Срібняк, Українці на чужині. Полонені та інтерновані вояки-українці в країнах Центральної та Південно-Східної Європи (1919-1924), Київ 2000, s. 77.

5 Centralne Państawowe Archiwum Wyższych Organów Władzy i Zarządzania Ukrainy (Центральний державний архів вищих органів влади та управління України, dalej - ЦААВО України), фонА 3570, опис 1, справа 22, аркуш 36. 
oraz miejscach pobytu cywilnej emigracji powstały akademickie organizacje o charakterze kulturowo-oświatowym ${ }^{6}$. Istniały one w wszystkich obozach internowania Ukraińców w Polsce m.in. w Wadowicach, Kaliszu, Łańcucie, Aleksandrowie Kujawskim, Siedlicach. Ich działalność była różnorodna, na przykład w Aleksandrowie Kujawskim oddział kulturalno-oświatowy planował wydawanie gazety ${ }^{7}$.

Życie w obozach było bardzo ciężkie. Materialny niedostatek, głód, epidemia tyfusu i czerwonki, złe traktowanie ze strony administracji, której zadania sprawowały oddziały wojska polskiego, przyczyniały się często do załamania psychicznego i fizycznego internowanych. Zasoby pieniężne przywiezione z Ukrainy zostały przejęte przez Polaków. Mimo, że internowani zostali pozbawieni bazy materialnej, rozwijali oświatę i szkolnictwo. Przy każdym obozie organizowano sekcje: ogólną, wydawniczą, historyczną, artystyczną, naukową, biblioteczną i sportową. Nauczanie odbywało się na różnych poziomach: podstawowym, gimnazjalnym, wyższym. Organizowano kursy języków obcych: angielskiego, niemieckiego, francuskiego i esperanto. Gimnazja utworzono w Łańcucie, Kaliszu, Szczypiornie i Strzałkowie .

W obozie w Łańcucie gdzie znajdowała się większa część internowanej Armii URL stworzono Komitet, który organizował życie jeńców i internowanych. Założono też Fundusz, z którego wspierano m.in. działalność kulturalno-oświatową wśród jeńców i internowanych Ukraińców ${ }^{9}$. Skupiała się ona m.in. wokół aktywności artystycznej np. organizacji koncertów i spektakli ${ }^{10}$.

W celu koordynacji działalności kulturalnej w Armii URL oraz poszukiwania nowych zasad jej organizacji, w Łańcucie 20-21 marca 1921 roku został powołany Zjazd pracowników kulturalno-oświatowych ukraińskich wojsk internowanych. Biorąc pod uwagę, że przyjechała tylko część przedstawicieli oddziałów kulturalno-oświatowych Armii URL (20 delegatów), organizatorzy postanowili uznać Zjazd za „spotkanie konferencyjne”. Podczas obrad przyjęto następującą rezolucję: „przedstawiciele organizacji kulturalno-edukacyjnych oddziałów Armii URL, po wymianie poglądów na temat poszczególnych raportów, stwierdzają że kwestie

6 Centralne Państwowe Archiwum Historyczne Ukrainy we Lwowie (Центральний дер-

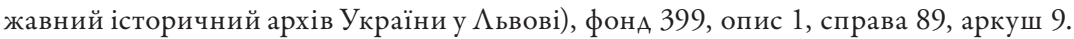

ЦААВО України, ф. 3570, оп. 1 спр. 15, арк. 48.

8 K. Paszkiewicz, Szkolnictwo i oświata wojsk Ukrainskiej Republiki Ludowej internowanych w Polsce w latach 1920-1924, [w:] Polska i Ukraina. Sojusz 1920 roku i jego następstwa, red. Z. Karpus, W. Rezmer, E. Wiszka, Toruń 1997, s. 330.

9 Archiwum Zakładowe Biblioteki Narodowej w Warszawie - „Archiwum Towarzystwa Naukowego im. Tarasa Szewczenki”, mikrofilm 92035, s. 160.

10 Centralne Państwowe Archiwum Ukrainiki Zagranicznej (Центральний державний apхів зарубіжної україніки, daleј - ЦААЗУ), фонА 15, опис 1, справа 71, аркуш 10. 
kulturalno-oświatowe oraz praca nad świadomością narodową w armii znajduje się na niskim poziomie. Ze względu na biurokratyczne metody jej wprowadzania przez kierownictwo, za konieczność uznaje się: konsolidację wszystkich kulturalno-oświatowych sił w zjednoczonym centrum, do jego formowania ma służyć komitet, składający się z pięciu osób z prawem doboru członków. Komitetowi poleca się niezwłocznie, nie później niż w ciągu 20 dni, powołać ogólną konferencję i przygotować dla niej należne raporty"11.

Zjazd wszechstronnie przebadał aktualny stan pracy kulturalnej i oświatowej oraz dostrzegł jej pozytywne i negatywne strony; przyjął raporty z tej działalności oraz zatwierdził wcześniej przygotowany plan ${ }^{12}$.

W trakcie konferencji zostały przyjęte następujące pozycje:

1. Przekazanie kontroli spraw kulturalno-oświatowych w armii z jurysdykcji Sztabu Generalnego do Ministerstwa Spraw Wojskowych, z jednoczesnym podporządkowaniem działu bezpośrednio ministrowi.

2. Powołanie stałego specjalnego korpusu pracowników kulturalno-oświatowych armii, jako samodzielną jednostkę.

3. Podniesienie świadomości narodowościowej w armii przez fachowe wychowanie wojskowe.

4. Powołanie samodzielnej kadry referentów oraz instruktorów kulturalnooświatowych przy oddziałach wojskowych.

5. Powołanie przy referentach kadry lektorów i propagandystów.

6. Rekrutacja do działalności kulturalnej i oświatowej w armii wykwalifikowanych cywilów (pedagogów, lektorów) dla stałej i czasowej pracy.

7. Organizacja w armii szkół podstawowych, średnich oraz zawodowych, gdzie można by kontynuować edukację ${ }^{13}$.

Realizacją programu zajęła się niezwłocznie Komisja Koordynacyjna. Na specjalnie zwołanej naradzie postanowiono zorganizować sieć wojskowego i cywilnego szkolnictwa wyższego, średniego i podstawowego ${ }^{14}$. Najwcześniej powstały w obozach szkoły dla analfabetów i półanalfabetów, w uruchamianiu których znaczniej pomocy udzieliło Stowarzyszenie Amerykańskiej Młodzieży Chrześcijańskiej (YMCA). Oprócz tego zorganizowano dla zainteresowanych wykłady z historii i geografii Ukrainy, a dla oficerów naukę języków obcych i zajęcia z musztry. Te formy aktywności wystąpiły we wszystkich obozach, w których

11 ЦААЗУ, ф. 15, оп. 1, спр. 71, арк. 25.

12 ЦААЗУ, ф. 15, оп. 1. спр. 71, арк. 94.

13 ЦААЗУ, ф. 15, оп. 1. спр. 71, арк. 56.

14 A. Kolańczuk, Ukrainscy generałowie w Polsce. Emigranci polityczni w latach 1920-1939, Przemyśl 2009, s. 47. 
przebywali Ukraińcy, najwcześniej i najliczniej zaś w Pikulicach, Aleksandrowie Kujawskim i Łańcucie ${ }^{15}$.

Na wspomnianej naradzie omówiono też funkcjonowanie Szkół Oficerskich w Łańcucie i Kaliszu; szkół podoficerskich; koncepcję dokształcania kadry oficerskiej na Akademickich Kursach Sztabu Generalnego Armii URL w Kaliszu; organizację sieci kursów maturalnych; kursów przygotowawczych do studiów wyższych; stworzenie sieci gimnazjów obozowych w tym gimnazjum skautów (płastuniw) z internatem w Szczypiornie i Kaliszu; kursów dokształcających dla kadry oficerskiej, w tym nauki języków obcych; kursów zawodowych dla szeregowców w różnych zawodach rzemieślniczych; organizację bibliotek. Dyskutowano również nad sprawą wyjazdów na studia do Czechosłowacji, gdzie funkcjonowały cztery wyższe uczelnie ukraińskie ${ }^{16}$.

Szkolenia prowadziły: Wspólna Młodzieżowa Szkoła Przygotowania Oficerów (starszyn), szkoły dywizyjne, Akademickie Kursy Sztabu Generalnego. W obozach powoływano nowe ośrodki kulturalno-oświatowe, których celem było narodowo-patriotyczne wychowanie wojskowych. Zakładano nie tylko szkoły, ale i organizacje artystyczno-literackie, wydawnictwa, trupy teatralne, wojskowe orkiestry i chóry. Koncerty i przedstawienia cieszyły się powodzeniem zarówno w obozach jak i poza nimi; organizowano je np. w Warszawie, Krakowie, Poznaniu, Przemyślu ${ }^{17}$. Oprócz koncertów w obozach dla rodaków, artyści występowali także dla publiczności polskiej w miejscowościach położonych w pobliżu obozów, choć nie tylko ${ }^{18}$.

Ukoronowaniem inicjatyw Ukraińców w dziedzinie oświatowej było otwarcie w Łańcucie Ukraińskiego Uniwersytetu Narodowego. Rektorem wybrany został prof. Wasyl Bidnow ${ }^{19}$. Pierwsze wykłady rozpoczęły się 10 czerwca 1921 roku w wydzielonym na ten cel obozowym baraku. Uniwersytet składał się z czterech fakultetów (wydziałów): historyczno-filozoficznego, matematyczno-przyrodniczego, wojskowego oraz ekonomicznego. Na początku zapisało się na studia około czterystu słuchaczy, pochodzących z różnych obozów. Na wykłady do obozu

15 Z. Karpus, Pobyt żotnierzy Ukrainskiej Republiki Ludowej w obozach internowania w Polsce w latach 1920-1924, [w:] Europa Orientalis. Polska i jej wschodni sąsiedzi od średniowiecza po wspótczesność: studia i materiaty ofiarowane Profesorowi Stanistawowi Alexandrowiczowi w 65 rocznice urodzin, red. Z. Karpus, T. Kempa, D. Michaluk, Toruń 1996, s. 458-459.

16 A. Kolańczuk, Ukraińscy generałowie w Polsce. Emigranci polityczni w latach 1920-1939, Przemyśl 2009, s. 47.

17 3. Кисімь, Украӥнське воєнно-історичне товариство (1920-1939), [w:] Український історичний журнац, №2, Київ 2001, s.102.

18 Z. Karpus, Pobyt żotnierzy Ukraińskiej Republiki Ludowej..., s. 459.

19 ЦААЗУ, ф. 15, оп. 1, спр. 71, арк. 83. 
w Łańcucie regularnie przyjeżdżali ukraińscy naukowcy z Tarnowa i Lwowa. Działalność uniwersytetu była kontynuowana również po przeniesieniu Ukraińców (na ich własną prośbę) z Łańcuta do Strzałkowa ${ }^{20}$. W Strzałkowie uniwersytet działał ze zwiększonym gronem studentów. Ich liczba znacznie wzrosła (do 758 osób ogółem), szczególnie na fakultecie wojskowym (do 235 osób: przeważnie oficerowie i podoficerowie). Ze względu na odległość nie wszyscy wykładowcy mogli dojeżdżać ze Lwowa i Tarnowa, dlatego powołano własne kadry profesorskie, zwłaszcza na wydziale wojskowym. Do zajęć na innych fakultetach zaproszono wykładowców m.in. z Poznania ${ }^{21}$. W nowym obozie w Strzałkowie Ukraińcy oprócz szkół elementarnych i uniwersytetu utworzyli także gimnazium ${ }^{22}$.

W ciągu 1921 roku działalność kulturalno-edukacyjna w obozach internowanych znacznie wzrosła, angażując coraz większe grono społeczności obozowej. Opisując inicjatywy w Strzałkowie jeden z byłych żołnierzy Armii URL wspominał: „Życie naszego obozu odbywało się we właściwym wszystkim obozom porządku. Od czasu do czasu w teatrze obozowym przedstawiano spektakle, organizowano koncerty, w audytorium praktycznie codziennie czytano wykłady na tematy wojskowe, a czasem również prezentowano referaty oraz wykłady na różne społeczno-polityczne tematy - bez tego życie w obozach byłoby nie do zniesienia. Mieszkańcy obozu byli przyzwyczajeni do tego, zdziwienie wywołałby fakt, gdyby któregoś jesiennego wieczora nie odbył się jakiśs wykład"23.

Urząd URL w Polsce stwarzał wojskowym sprzyjające warunki do studiowania. Według danych Ukraińskiej Komisji Eliminacyjnej w 1922 r. w obozach internowania znajdowało się około 350 osób, którzy pragnęli podjąć naukę na polskich wyższych uczelniach ${ }^{24}$. Wprowadzono zasady, zgodnie z którymi wykreślano z listy internowanych:

a) kiedy student został wpisany na listę jednej z wyższych szkół Polski;

b) kiedy student wyjechał z Polski.

W tym celu do władz polskich zwracała się Ukraińska Komisja Eliminacyjna. Studentom z obozów internowania dawano urlopy (do 22 miesięcy), przeznaczone na studia. Urlop mógł zostać anulowany, jeżeli student nie mógł, albo nie chciał zacząć nauki w wyznaczonym terminie. W takich przypadkach wracali oni do

20 Z. Karpus, Jeńcy i internowani rosyjscy i ukrainscy w Polsce w latach 1918-1924, Toruń 1991, s. 120 .

21 K. Paszkiewicz, op. cit., s. 332.

22 Z. Karpus, Jeńcy i internowani..., s. 120.

23 ЦААЗУ,. .15 , оп. 1, спр. 67, арк. 25.

24 ЦААВО України, ф. 3570, оп. 1, спр. 14, арк. 9. 
miejsc internowania ${ }^{25}$. Początkowo stosunek polskiej władzy nie był zbyt przychylny do studentów Ukraińców, dlatego internowani przebywający w obozach zmuszeni byli zwracać się do Ministerstwa Spraw Zagranicznych, Ministerstwa Spraw Wewnętrznych i Ministerstwa Wyznań Religijnych i Oświaty o zgodę na urlop ${ }^{26}$.

W czasie urlopów zakładano możliwość uzyskania pomocy materialnej tym studentom-wojskowym, którzy pragnęli kontynuować edukację na wyższych uczelniach. Otrzymanie jej było dość skomplikowane. Liczne wnioski, kierowane do urzędu URL były odrzucane. Stypendia wynosiły średnio od 15 do 25 tys. marek polskich ${ }^{27}$. Według innych danych w 1922 r. było 360 studentów wojskowych Armii URL. Wnioskowali oni o wypłatę 8 tyś. marek miesięcznie ${ }^{28}$. Do urzędu URL wpływały liczne prośby o pomoc, w których sugerowano:

a) by studentom-wojskowym przy zwolnieniu ze służby w celu ukończenia studiów wypłacać pieniężne zaległości z ich służby wojskowej w walucie polskiej;

b) by studentom-wojskowym przy zwolnieniu ze służby w celu ukończenia studiów wypłacać jednorazową pomoc na zakup cywilnej odzieży i obuwia (podobnie jak urzędnikom cywilnym);

c) by wszystkie wypłaty studentom-wojskowym przy zwolnieniu ich na urlop w celu ukończenia studiów odbywały się w czasie rekrutacji do szkół wyższych $^{29}$.

Problemem było to, że większość studentów ze środowiska byłych wojskowych nie miało ze sobą oryginałów dokumentów poświadczających ich wykształcenie. Komplikowało to procedury rekrutacyjne na wyższe uczelnie w Polsce. Dlatego Ministerstwo Oświaty URL zbierało informacje o wykształceniu każdego studenta i na podstawie zebranych dokumentów wydawano certyfikaty. Zamieszczano w nich informacje o ukończonych szkołach, lecz nie podawano ocen. Wykluczało to chętnych do studiowania np. w Wyższej Szkole Handlowej w Warszawie gdyż decyzję o przyjęciu do niej podejmowano na podstawie konkursu świadectw ${ }^{30}$.

W międzywojennej Polsce studenci ukraińscy mieli możliwość studiowania i prowadzenia działalności naukowej w takich centrach edukacyjnych jak Warszawa, Kraków, Poznań i Gdańsk (Wolne Miasto Gdańsk). Studiowanie wychodź-

\footnotetext{
25 ЦААВО України, ф. 3570, оп. 1, спр. 14, арк. 13.

26 ЦААВО України, ф. 3570, оп. 1, спр. 13, арк. 214.

27 ЦААВО України, ф. 3570, оп. 1, спр. 13, арк. 114.

28 ЦААВО України, ф. 3570, оп. 1, спр. 13, арк. 166.

29 ЦААВО України, ф. 3570, оп. 1, спр. 13, арк. 59.

30 ЦААВО України, ф. 3570, оп. 1, спр. 32, арк. 204.
} 
ców z ziem (które nie należały do Polski po I Wojnie Światowej) na uczelniach Lwowa i Wilna, Ukraińskie Zgromadzenie Studentów (jako główna organizacja studenckiej emigracji w Polsce) uważało z przyczyn politycznych za niemożliwe. Studentów z ziem centralnej Ukrainy traktowano zarówno władze uczelni oraz studenci przychylnie ${ }^{31}$. Ukraińska Misja Dyplomatyczna także wnioskowała do Ministerstwa Wyznań Religijnych i Oświaty o zezwolenia na studia dla byłych ukraińskich wojskowych. Odpowiedź zazwyczaj była pozytywna pod warunkiem posiadania wolnych miejsc przez uniwersytety ${ }^{32}$. Biorąc pod uwagę sprzyjające studiowaniu okoliczności, gościnność polskich szkół wyższych, studenci ukraińscy zobowiązywali się do utrzymywania polityki niewtrącenia się w wewnętrzne polskie spory i konflikty ${ }^{33}$. Praca akademicka oraz życie ukraińskich studentów na emigracji oparta była głównie na działalności kulturalno-narodowej ${ }^{34}$.

Po I Wojnie Światowej i wojnach wyzwoleńczych wykształcił się nowy obraz ukraińskich studentów okresu międzywojennego. Były nimi osoby, które po trudnych przeżyciach wojennych zmuszone były szukać możliwości kontynuowania nauki za granicą. Wśród nich byli i tacy, którzy z różnych przyczyn (głównie politycznych) nie mogli zdobyć wyższego wykształcenia na ziemiach ukraińskich. Obok edukacji istotne było dla nich także odrodzenie państwa ukraińskiego w przyszłości oraz godne reprezentowanie narodu na arenie międzynarodowej.

31 ЦААВО України, ф. 3570, оп. 1, спр. 13, арк. 20.

32 ЦААВО України, ф. 3570, оп. 1, спр. 13, арк. 17.

33 ЦААВО України, ф. 3570, оп. 1, спр. 13, арк. 20.

34 ЦААВО України, ф. 3570, оп. 1, спр. 22, арк. 7. 